\title{
On Chinoiserie Design \& Japanning in the University of Coimbra's Biblioteca Joanina
}

The Joanine Library (the "Old Library") at Portugal's University of Coimbra was built between 1717 and 1728 during the reign of King João V. Inside the Joanine Library, with the exception of the ceiling, many of the interior surfaces-columns, walls, bookshelves, and doors-are colored in black or vermillion "japanning" and decorated in the Chinesestyle designs known as "chinoiserie." In this paper, I present the results of my study of this interior, considering why such japanning and chinoiserie were selected for the interior design and introducing some of the significant design elements I was able to identify within these. Relationships between various world regions and Europe clearly defined the places of the art created in those regions, but routes of exchange at that time were much broader than merely "toward Europe." The Old Library at the University of Coimbra is one representative example, built using gold and wood brought from Brazil, offering an entirely European baroque appearance outside, but decorated in chinoiserie within. In the Old Library we see the results of an attempt, motivated purely by intellectual curiosity and quite apart from Western intentions of discovery or conquest, to integrate aspects of a different culture and a new aesthetic. Through my survey and analysis of the panels within the Old Library, my intention is to gain some insight into the views of Asia held by the Portuguese of that time.

keywords the Joanine Library, Coimbra University, chinoiserie, japanning, cross-culture

\section{Introduction}

The Joanine Library (Biblioteca Joanina, the "Old Library") at Portugal's University of Coimbra was built between the years 1717 and 1728 during the reign of King João V. ${ }^{1}$ It has been designated a world heritage site, known particularly for its magnificent baroque architecture and considered among the most beautiful libraries in the world, ${ }^{2}$ and even today remains a cherished reminder of the Portugal's days of prosperity and splendor. Inside the Joanine Library, many of the interior surfaces-columns, walls, bookshelves, and doors-are colored in black or vermillion "japanning" and decorated in the Chinesestyle designs known as "chinoiserie." Having obtained permission from the University of Coimbra, in 2013 I undertook a survey of all 336 wall panels within the Old Library and classified them by motif, and here I will use my analysis of these results and these designs to try to understand something of the view the Portuguese had of Asia at that time, as manifested in their chinoiserie and japanning. 
Figure 1.

The furthest of the three chambers in the Old Library. (Photo by the author, (c) University of Coimbra)

\section{Portuguese Prosperity through the Wealth of Brazil}

Portugal was one of the first nations out of the gate during the age of European overseas expansion. From 1693 on, Portugal was discovering vast gold deposits in its Brazilian colonial outposts, beginning what was to become literally a "golden age" for the nation. The pinnacle of this national prosperity coincided with the reign of King João V (16891750), under whose aegis the baroque library at the University of Coimbra was originally constructed. ${ }^{3}$

Gold production in Brazil expanded rapidly starting in the 1720s, and eventually hit its zenith in Minas Gerais during the twenty-year period from 1735 to $1754 .{ }^{4}$ Brazilian gold made possible talha dourada, the rich gold gilding that was used to ornament Portugal's baroque art. ${ }^{5}$ Further, from the Age of Discovery on, reflecting the nation's superintendence over its activities in Asia and the influences flowing from those affairs, Portuguese artisans began introducing images done in the so-called "chinoiserie" style, including applying gold gilding over japanning, itself an imitation of Japanese urushi (lacquer). The Portuguese empire that began in the 16th century was essentially an oceangoing empire, one in which control of the seas was the lifeline that maintained it, and its embrace of artistic techniques and styles like japanning and chinoiserie can be seen as symbolizing its dominance of the sea routes between Europe and India.

\section{The "Old Library" - The University of Coimbra's Joanine Library}

The University of Coimbra was established in 1290 by Portugal's King Dinis I, and its library at that time was in Lisbon. During the reign of João $V$ this library was built as a baroquestyle cenotaph. The project to construct the current building began with a letter written by university rector Nuno da Silva Teles to King João V in 1716. ${ }^{6}$ Having obtained sanction from the royal household, on October 31, 1716 he began work on the new building. The initial construction, which incorporated a portion of the former Royal Palace of Coimbra, took from 1717 through to $1728 .^{7}$

The building is done in the baroque style, divided into three separate halls, including shelving on the second floor, as shown in Figure 1.

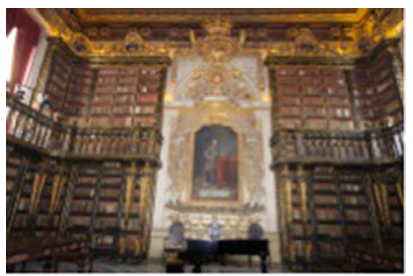

The first person to commence work on the library was João Carvalho Ferreira, a master builder working in the university's service. Within a year, however, Ferreira's ability to

\footnotetext{
${ }^{3}$ Birmingham, D., (translation by Takada, Y) History of Portugal, Cambridge Concise Histories, Tokyo: Sodosha, p100

${ }^{4}$ Kanashiro, N.(2009), History of Brasil, Tokyo: Toyo Shoten, p6o

5 Tateishi, H. (1996) History of Portugal, Tokyo: Sairyusha, p151

${ }^{6}$ Burton, M. (1937) Famous Libraries of the World, London: Grafton \& Co., p319

7 Fiolhais,C. (2013), Joanina, Comibra:University of Coimbra, p16
} 
handle the project fell under doubt, and he was replaced by Gaspar Ferreira. ${ }^{8}$ Despite having no formal training, in 1718 Gaspar Ferreira was entrusted with the construction of the library, including in particular its shelving, and from then until his death in 1761 he would be involved in numerous baroque-style construction projects, the ongoing work on the library among them.

The religious images on the inside of the library's ceiling dome were painted by artists António Simões Ribeiro and Vicente Nunes, but turning to the chinoiserie that is our main subject of consideration here, the individual concerned was one Manuel da Silva, a decorative artist who also dabbled in figurative painting, born in Lisbon and trained at the school of Vicenzo Bacherelli. Relocating to Coimbra to work on João V's library, in 1723 he was placed in charge of gilding and lacquering the shelves. The left of Figure 1 shows the furthest of the three chambers, including a portrait of King João there on the facing wall. The panels in this room, including those in between the shelves, on both the first and second floors, are decorated in chinoiserie designs like those shown on the right of Figure 1.

\section{“Japanned" Walls}

The three halls in the Old Library are all 4.5 meters wide, the naves of the front and far halls are both 10.14 meters deep, and that of the middle hall is 10.46 meters deep. The walls of the front and far rooms are decorated in black japanning, the middle room in vermillion. The panel shown in Photo 1-2 is done in black japanning. This photo was taken in mid-summer, and the strong summer sun makes the black appear green, but similar surfaces downstairs and other areas where the sunlight does not reach appear jet black. However, although this kind of japanning can be called black, Dr. Oliver Impey, in his book Chinoiserie, calls it "japanned green" because of its green tints. ${ }^{9}$

"Japanning" was a decorative coloring technique that attempted to imitate the lacquer work of Japan and China, typically in blacks, reds, and greens, although colors were also sometimes included. The trees yielding the specific sap essential to the production of such lacquers were cultivatable only in Japan, China and certain other regions of the Far East and Southeast Asia. Attempts to transport this lacquer sap back to Europe usually resulted in the material hardening prematurely during the voyage, causing European countries that coveted Japanese lacquer to use such imitation lacquers.

The blacks and reds offered by japanning offered an ideal backdrop for highlighting chinoiserie's gold-gilded motifs, and the combination was an excellent choice for imparting an "Oriental" feel. It also happened that such techniques and materials were not used to decorate European churches.

Lampblack and a variety of other materials were tried for pigmenting the imitation lacquers used in japanning, but determining the exact composition of these now has proved no easy task, and one that will undoubtedly require study by specialists in the field. One thing we can say, however, is that the imitation lacquers used in japanning seem to have offered one excellent advantage over the real thing, namely, a durability that has maintained their blacks and reds as vibrant today as they were when first applied 300 years ago. It's true that some portions, particularly on the second floor of the Old Library,

\footnotetext{
${ }^{8}$ Amaral, A.E. M.( 2011) Tesouros Da Biblioteca Geral Da Universidade de Coimbra, Coimbra:Universy of Coimbra,p6

9 Impey, O(1977). Chinoiserie, London: Scribners, p166
} 
theme 6

open strand

Table 1.

Classification of designs by position in the Old Library ( $\mathrm{H}=$ Human, $F=F l o w e r s, B=B i r d$, $\mathrm{P}=\mathrm{Pagoda}, \mathrm{T}=$ Tree have peeled somewhat due to damage from long exposure to sunlight, and some areas have obviously been repaired and restored. But consider, too, that the reign of João V coincided with the peak of Portugal's prosperity, such that its power would only gradually decline thereafter, and, like other structures built at the time, assumedly also at the peak of quality, there would eventually be insufficient monies in the national coffers to maintain and repair them on an ongoing basis. Had the walls of the baroque library been decorated in true lacquer, the strong Portuguese sunlight and dryness probably would have washed out the vibrant colors and caused peeling within not too long a time. The use of the imitation lacquer of japanning has ensured that the original look remains quite well preserved even today.

\section{Chinoiserie Designs}

The Old Library includes a total of 336 wall panels, 112 on each floor including 28 (including 4 on the doors) in each of the first floor rooms, and 84 on the second floor. Except for the ceiling dome itself, with its depiction of religious allegory, all are decorated in chinoiserie designs over japanning, including the spaces around each of the panels, the columns, the shelves, and the colonnades extending up to the ceiling dome.

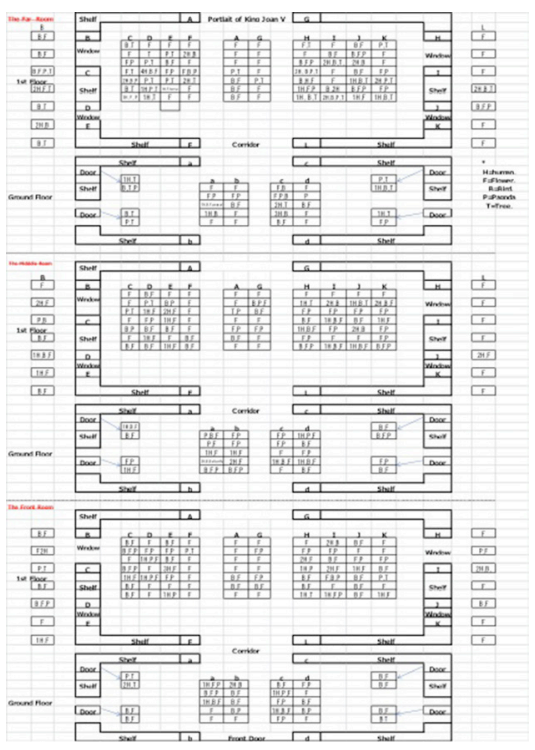

I have classified the various panel motifs broadly as human, flower, bird, pagoda and tree(Table 1). There are also other designs, like snails, insects, etc., on other areas, such as in the centers of doors, but for this purpose I will limit the discussion to those appearing on the panels.

Flowers sometimes appear on their own, but more often they are depicted in combination with trees, rocks, and pagodas, and it probably is safe to assume that these were based on the so-called "beauties of nature" designs encountered on Chinese-made porcelains and lacquer wares. Flowers on their own are found on 107 out of the 336 panels-roughly a third of them-and 60 more contain flowers in combination with birds, followed by 19 
with combinations of birds, flowers, and pagodas. As these numbers show, flowers are the most common motif, appearing on about half of the panels. While some are clearly identifiable-like cotton roses and water lilies-the majority are of a more generic nature with few distinguishing characteristics.

It is possible to distinguish men and women by their hairstyles, expressions, and clothing, but in some cases the artlessness of the image makes it impossible to identify genders.

However, as can be seen in Figure 2, among the "Chinese" people depicted, there are many for which it would be difficult to say that they were, in fact, Chinese, and from an Asian perspective they could just as well be Westerners. The maximum number of such human figures appearing on any one panel is four.

As far as structures go, pagodas are prominent. These look like anything from gazebos to houses to temples, but in the West all of these could be considered "pagodas," so we can classify all of them as such.

All of these various drawings demonstrate a variety of levels of artistry, probably due to variations in the artistic skill of the gilders who drew them.

\section{Examples of Chinoiserie in Other Portuguese Buildings}

Other examples of chinoiserie in Portugal include the "Chinese Room" in the University of Coimbra's law department library, constructed according to a legally sanctioned reform by decree on April $18^{\text {th }}, 1911 .^{10}$ This room, an almost perfect square measuring 5.99 by 5.71 meters, has walls decorated in a base coat of green, overlain by panels and surrounding areas done in chinoiserie designs.

Many of the chinoiserie motifs appearing in this room were clearly done in imitation, or were outright copies, of those in the University's Old Library. The biggest difference between the two is that the Old Library has a Christian image painted on its ceiling dome, while the law department library's ceiling is decorated entirely with green pigment overlain with chinoiserie to give the whole room a very unified effect.

\section{Conclusion}

Relationships between various world regions and Europe clearly defined the places of the art created in those regions, but routes of exchange at that time were much broader than merely "toward Europe." The Old Library at the University of Coimbra is one representative example, built using gold and wood brought from Brazil, offering an entirely European baroque appearance outside, but decorated in chinoiserie within. This seems a very good expression of the Portuguese worldview at that time: the "other world" of Christianity in the dome above; the everyday world below, built from wood harvested in Portuguese colonial Brazil and decorated in talha dourada of Brazilian gold; in chinoiserie designs imitating lacquer from Asian excursions; and an external appearance fully demonstrating the preeminence of Western baroque architecture.

Chinoiserie is seen here in mid-1 $7^{\text {th }}$ century architecture, but as an art form it had little to do with art being produced in China, and was a purely European artistic motif. Looking at the wall panels in the Old Library, this can be seen most clearly in the depictions there of human figures, and the concept of Chinoiserie in general, as understood by the Portuguese at the time the Old Library was built, can be seen in their depictions of flowers, pagodas, and "Chinese" people (as they imagined them).

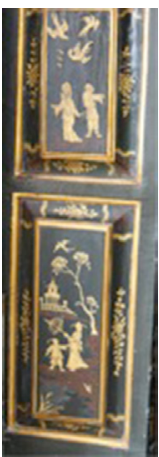

Figure 2.

Chinoiserie-decorated panels on the right side of second floor of the furthest chamber These panels are located in the lowest and second lowest positions under "I" in Table 1 above.

\footnotetext{
${ }^{10}$ Faculdade deDireito (2013), Faculdade de Direito da Universidade de Coimbra, Coimbra: University of Coimbra, p56
} 
There are many questions that remain about the cross-culture milieu between the West and the East, but the perspective from an angle of seafaring culture history, which allows the overall picture to be created through verification of the interaction of art introduced by trade ships beyond Japan-Europe relations, will be a useful starting point for future research.

\section{Major Sources Consulted}

Amaral, A.E. M. (2011) Tesouros Da Biblioteca Geral Da Universidade de Coimbra, Coimra: Universy of Coimbra.

Birmingham, D. (2002) (translated by Takada, D.) History of Porugal, Cambridge Concise Histories, Tokyo: Soudosha.

Fiolhais, C. (2013), Joanina, Coimbra: University of Coimbra.

Impey, O. (1977), Chinoiserie, London: Scribners.

Kinhichi, N. (2010) A History of Portugal, Tokyo: Kawade Shobō Shinsha.

Ibid. (2009) History of Brasil, Tokyo: Toyo Shoten.

Mendes, P. and Fiolhais, C. (2913) Joanina,Coimbra: University of Coimbra

Stierlin, H \& A. (1994) Baroques d'Espagne e du Portugal, Lisbon: Imprimerie Nationale

Tateishi, H. (2913) History of Spain and Portugal, Tokyo: Yamakawa Publishing, 2000

The author would like to thank the following for their cooperation in making this artistic study possible: The University of Coimbra; the Joanine Library; A. E. Maia do Amaral Biblioteca Geral da Universidade de Coimbra; Professor Alexandra Aragao of the Faculty of Law, University of Coimbra. 